\title{
Historical Evolution of Intermarriages between China and the West and Differences between Chinese and Western Traditional Concept of Love and Marriage
}

\author{
Ping Yang \\ School of Foreign Language \\ Kunming University \\ Kunming, Yunnan, 650214 \\ Min Zheng \\ School of Foreign Language \\ Kunming University \\ Kunming, Yunnan, 650214
}

\author{
Shi Qian \\ School of Fine Art and Design \\ Kunming University, Kunming \\ Yunnan, 650214 \\ Yun Cai \\ School of Foreign Language \\ Kunming University \\ Kunming, Yunnan, 650214
}

\begin{abstract}
With the increasingly frequent exchanges between China and the West, the scope of exchanges has expanded from the economic and cultural fields to a deeper and broader level. With the increase of contacts between Chinese and westerners, it is natural to fall in love with and get married to each other. The phenomena of intermarriages between Chinese and westerners are also increasing. Intermarriages help to promote understanding among nations, but because of differences in customs and cultural concepts, such marriages are often in crisis, such as some cracks, or even the dissolution of marriages. People should learn to think differently, put themselves in the other's shoes from the perspective of different cultural backgrounds, instead of understanding and measuring each other according to the concepts and standards of their own national culture, and jointly safeguard their marriages and family.
\end{abstract}

Keywords - Intercultural communication awareness; Love and marriage; Cultivation of cross-cultural communication awareness

\section{HistoricAl EVOLUTION OF INTERMARRIA GES BETWEEN CHINA AND THE WEST}

China was defeated by the Western powers in the Opium War. Under such a background, the early foreign-related marriages appeared. At that time, although China was poor and weak, the first group of people who had chances to contact with the westerners were almost all high-ranking officials with prominent social status, so in the few cases of intermarriages between China and the West, most of the brides were Chinese and most of bridegrooms were Europeans or Americans.

${ }^{[1]}$ Early intermarriages were the results of free choices among Chinese and westerners. Compared with the arranged marriages of parents, which were still popular in China at that time, they were models of early free marriages. Chinese people who married foreigners often had special experiences and identities. One of the early types of intermarriages are the marriages between Chinese envoys and overseas students. Chen Jitong (1851-1905), a scholar in the late Qing Dynasty, lived in the West for more than 20 years as a translator and counselor and married a French woman. ${ }^{[2]}$ Another type of early intermarriages is those between foreigners in China and the Chinese people.

After decades of isolation from the West, China restarted contacts with other countries since its reform and opening-up. At that time, Chinese people were full of curiosity about foreign countries and foreigners. With the increasing contacts between Chinese and westerners, it is natural for them to fall in love with and get married to each other. However, due to the backward economy of China, the marriages between China and the West at that time were dominated by women marrying foreigners. Many of the most popular female stars married far away to Europe and the United States. ${ }^{[3]}$

In recent years, with the increasingly frequent exchanges between China and the West, transnational marriages have been nothing new. Intermarriages between Chinese and westerners have become a common occurrence, ranging from high-ranking officials to ordinary people. Then, the trouble comes: there are big differences between Chinese and Western concept of love and marriage. How should a couple in a foreign marriage handle their relationship? 


\section{Chinese and Western Traditional ConcePt of love} AND MARRIAGE

\section{A. Chinese Traditional concept of love and Marriage}

Chinese traditional concept of marriage is relatively implicit, cautious and conservative. In literary works, daily necessities such as silk handkerchiefs, moon-shaped fans, hairpins, red beans and black hair are used to express yearnings and love. ${ }^{[4]}$ People long for the exciting aspect of love and fear the painful aspect of love. This contradiction originates from the traditional moral concepts of the Orient. Marriage is not only a choice of personal will, but also something trending toward a guarantee of survival. As a marriage is mixed with too many moral, economic and social factors, people have contradictory and complex mentalities about marriage. ${ }^{[5]}$

1) Chinese traditional concept of selecting a mate and getting married.

Love in the Orient has too many connotations, including family, wealth, status, reputation, ethics, filial piety and etiquette. In Liang Shanbo and Zhu Yingtai, Ma Wencai's marriage arrangement with Zhu Yingtai is a tragedy with the influence of feudal traditional ideas on marriage and love. For women, they "marry a man for foods and clothes". Marriage is more likely something trending toward a guarantee of survival for women who were not financially independent. As far as the Chinese are concerned, since the time of Confucius, love has been regarded as something in which "only the poor and bored expressed their sentiments". In marriage, love was seldom talked about, with more considerations given to the other's social status, economic status, culture, age and reproduction. With the progress of the society, arranged marriages with "orders from parents, words from matchmakers" and ignorance of the parties concerned had gradually withdrawn from the historical stage decades ago. Its influence on the ideas of mate selection in China has basically disappeared. As China becomes economically stronger and the woman is more financially independent, the ideas of mate selection in China now tend to be based on the mutual love between men and women. In selecting a spouse, they generally do not take the family status and the wealth as a condition, but give more attention to the virtues, talent and appearance of the other side.

\section{2) The relationship between family and career.}

In Chinese culture, the collective orientation dominates. In China, since ancient times, there was a great example of $\mathrm{Yu}$, the Great Taming the Flood who "did not enter his home in his three passing". ${ }^{[6]}$ The mainstream ideology also propagates the consciousness of taking the country first and the home second, the public first and the private second, maintaining that a Chinese should not indulge in love affairs and know nothing about the larger issues. There is a saying of "prioritizing the big family (the country) before a small one (a personal family)". If a man sacrifices the collective interests for his own sake, he will be considered too selfish. Chinese mainstream media often eulogize the story of an athlete or a soldier who stays at his or her post after his or her family members get sick or even die.

3) Chinese concept of marriage under the family views

Chinese traditional concept of marriage under the family views generally stresses a harmonious unity lasting over one hundred years and a choice of marriage for a lifetime. As China is a country of courtesies, once married, Chinese people emphasize their responsibilities to families, especially after having children. Even if they don't love each other anymore, in most cases, they will choose to maintain their marriage for the sake of their children, family affection, morality, responsibility, and family stability. In order to provide a good living and learning environment for their children, many couples will stick to their marriages until their children finish the college entrance examination or graduate from colleges. Divorce is often considered immoral. Chinese people believe that once they get married, they should not divorce easily.

\section{B. The Concept of Love and Marriage in the Western Society}

There are great differences between Chinese and Western concepts on love and marriage. The Western view of love is more enthusiastic and unrestrained. They enjoy warm and straightforward expressions, even love at first sight. In the Western concept of love, love is the most sacred part of human feelings, Love is supreme. Westerners advocate democracy. They believe that marriage is a personal affair and love has nothing to do with marriage, descent, age, social status and other factors.

1) Western traditional concept of selecting a mate and getting married.

Westerners believe that choosing a spouse and marriage are personal problems, and no one can interfere in other people's private life. Westerners do not value age, appearance, financial status and marriage history when choosing a spouse, so Cinderella and the prince live happily together; Jane Eyre and Rochester in Jane Eyre can be free from all the old customs and prejudices, and obtain happiness.

2) The relationship between family and career.

In the West, the mainstream view is that family is more important than career. When there is a serious conflict between careers and family, career should be placed in the second place. There is such a thing that NBA fans all over the world love to talk about. In the process of competition with Jazz, Rockets top player McGrady taught his fiancee Harris was sent to the hospital and was about to give birth. Maddie was very anxious and he immediately changed his jersey and hurried to the hospital. An hour later, their son was born and the Rockets lost. No one blamed McGrady and his coach said: "We lost not because he wasn't here, but because we were incompetent in attack." ${ }^{[7]}$ Anyone who familiars with the NBA knows that as long as something big happens to the NBA players' families, there is no doubt that their leave will be granted even in the Finals.

3) Western concept of marriage in individual views.

Westerners advocate equality for all. Especially after the women's movement in nineteenth century, they tended to emphasize equality between men and women. There is no responsibility and obligation between the husband and the wife. When they eat out, if both sides have income, they may pay separately. Love is the foundation of marriage, and marriage without love is immoral. When Westerners are in love, they are in love with great vigor and vitality. When they don't love each other, they can also go to pursue their next romance. Divorce has nothing to do with morality. Once one of them finds that 
marriage is a mistake, he or she can make a second choice. If one of them falls in love with others, it will not be condemned. Westerners believe that it is immoral to let two people who do not love each other live together. In the United States, less than 10 percent of couples live together and raise their children together. Single-parent families account for more than half of the actual marriage in the United States. ${ }^{[8]}$

\section{Cultivation of Cross-Cultural Communication AWARENESS}

There are great differences in the attitudes, expressions and connotations of and the relationship between love and marriage between China and the West. When dealing with a transnational marriage, people should learn to think differently, put themselves in the other's shoes from the perspective of different cultural backgrounds, instead of understanding and measuring each other according to the concepts and standards of their own national culture, so as to interact harmoniously in the marriage life. ${ }^{[9]}$ Furthermore, people should learn to understand and adapt to each other's culture. The culture of any people reflects its history and characteristics and remains as the crystallization of its wisdom. People should learn to observe foreign cultures, respect them and take the initiative to adapt and understand them. As each culture has its own unique value system, people cannot consider one culture is good, and the other culture is bad. Every culture in their cultural system has its own rationality. In getting along with each other, people should communicate at any time; avoid misleading and hurt as much as possible, so as to maintain the marriage and the family.

\section{CONCLUSION}

The concepts of love and marriage among different peoples reflect their cultural views. Different cultural views stem from the values, modes of thinking and modes of behaviors of different peoples. With the increasingly frequent exchanges between China and the West, cultures between countries have been exchanged and complementary. In modern society, the Chinese concept of marriage is increasingly westernized, with marriages increasingly regarded as the embodiment of individual happiness and individual rights. After their extreme individualism, Westerners also tend to return to their families. ${ }^{[10]}$ A normal, stable and healthy society needs the concepts of marriage between Chinese and western cultures complementing each other. As Gong Haiyan, an expert of China's largest dating website, maintains, a truly beautiful concept of love is achieved by adhering to the responsibilities and warmth of the Orient, absorbing the honesty and unrestrained feature of the West, believing in and actively pursuing a true love. ${ }^{[11]}$ Although the concepts of love and marriage are widely different in places all over the world, let us respect other people's traditions and cultures and strive to be happy.

\section{REFERENCES}

[1] A Precedent for Intermarriage between China and Foreign Countries. [2015-3-22]. http://blog.sina.com.cn/s/blog_90cdccac0102vpbo.html.

[2] Ibid.

[3] Ibid.

[4] Li Wei. A brief Analysis of the Differences of Marriage between China and the West and the Causes [J], Jilin: Examination Weekly, 2015 (54): 25-26.

[5] Chen Xin. Comparison of Traditional Chinese and Western Love Concepts [J], Jiangsu: Culture and Education Materials, 2010 (1): 31-32.

[6] Misconceptions of Western Marriage in China. http://news.sina.com.cn/c/2009-02-09/142017177852.shtml

[7] My View of Family Marriage--A Comparis on of Chinese and Western Views of Family Marriage. https://wenku.baidu.com/view/e8a97d14fad6195f312ba662.html.

[8] Westerners' Views on Marriage -- Love and Marriage of Westerners http://www.360doc.com/content/10/0318/19/950298_19291620.shtml.

[9] Sun Jianjun. Differences between Chinese and Western Cultures in Concepts of Marriage and Love[J] Liaoning: Journal of Liaoning Vocational and Technical College of Economic Management, 2007, 36 (4): $152-152$.

[10] Li Wei. A brief Analysis of the Differences of Marriage between China and the West and the Causes [J], Jilin: Examination Weekly, 2015 (54): 25-26.

[11] What Are the Differences between Chinese and Western Views of love? [2014-12-18]. https://wenku.baidu.com/view/cd5bc4997c1cfad6185fa 726.html. 